\title{
Platinum Nanoparticles: Green Synthesis and Biomedical Applications
}

\author{
Sherif Ashraf Fahmy 1,2® ${ }^{1}$ Eduard Preis ${ }^{3} \oplus$, Udo Bakowsky ${ }^{3, *}$ \\ and Hassan Mohamed El-Said Azzazy ${ }^{1, *}$ \\ 1 Department of Chemistry, School of Sciences \& Engineering, The American University in Cairo, \\ AUC Avenue, P.O. Box 74, New Cairo 11835, Egypt; sheriffahmy@aucegypt.edu \\ 2 School of Pharmacy, University of Hertfordshire-Egypt hosted by GAF, R5 New Garden City, \\ New Administrative Capital AL109AB, Cairo 11835, Egypt \\ 3 Department of Pharmaceutics and Biopharmaceutics, University of Marburg, Robert-Koch-Str. 4, \\ 35037 Marburg, Germany; eduard.preis@pharmazie.uni-marburg.de \\ * Correspondence: ubakowsky@aol.com (U.B.); hazzazy@aucegypt.edu (H.M.E.-S.A.); \\ Tel.: +49-(0)-6421-28-2-58-84 (U.B.); +20-2-2615-2559 (H.M.E.-S.A.)
}

Received: 24 September 2020; Accepted: 26 October 2020; Published: 28 October 2020

\begin{abstract}
Platinum nanoparticles (PtNPs) have superior physicochemical properties and great potential in biomedical applications. Eco-friendly and economic approaches for the synthesis of PtNPs have been developed to overcome the shortcomings of the traditional physical and chemical methods. Various biogenic entities have been utilized in the green synthesis of PtNPs, including mainly plant extracts, algae, fungi bacteria, and their biomedical effects were assessed. Other biological derivatives have been used in the synthesis of PtNPs such as egg yolk, sheep milk, honey, and bovine serum albumin protein. The green approaches for the synthesis of PtNPs have reduced the reaction time, the energy required, and offered ambient conditions of fabrication. This review highlights the state-of-the-art methods used for green synthesis of PtNPs, synthesis parameters, and their reported biomedical applications.
\end{abstract}

Keywords: green synthesis; biosynthesis; platinum nanoparticles; anticancer; antioxidant; antibacterial; antifungal

\section{Introduction}

Platinum nanoparticles (PtNPs) have gained attention as promising tools for biomedical applications [1,2]. They exhibit unique optical properties that can be optimized by adjusting their sizes and shapes. PtNPs possess a localized surface Plasmon resonance, lead to a distinctive absorption band in the UV/Vis region, which is not displayed by the bulk forms [3,4]. Several physical and chemical approaches have been developed for the fabrication of PtNPs, including lithography, laser ablation, aerosol techniques, sol-gel techniques, co-precipitation, chemical reduction, and photochemical reduction. However, these methods are expensive and involve toxic reagents and synthetic stabilizers that may impact the environment and human health [5-7]. Green synthesis approaches that involve eco-friendly biological systems have been developed for the synthesis of PtNPs. Plants and their extracts were used for single-step, cost-effective biosynthesis of PtNPs. Plant extracts harbor various bioactive metabolites that could act as bio-reductants and stabilizers during the green synthesis of PtNPs [8-11]. In addition to plants, other biological entities were employed for green synthesis of PtNPs, including microbes (such as bacteria, viruses, fungi, and yeast) and marine algae [12-26]. The use of microbes as a potential biogenic route for the fabrication of PtNPs has some advantages, including their ease of production and capability to reduce $\mathrm{Pt}$ ions via enzymatic activity into the zero-valent $\mathrm{Pt}$ 
while maintaining optimum control over the average particle sizes [27]. Additionally, the use of microbes does not involve the use of toxic synthetic reagents, and many microorganisms operate at ambient temperatures [28]. On the other hand, the use of microbes in the biogenic synthesis of PtNPs involves a complicated and tedious multi-step procedure. Since culturing methods and optimization are very crucial, a sterilized environment should be maintained (to prevent cross-contamination by other microorganisms), and the culture conditions should be optimized for light, temperature, $\mathrm{pH}$, inoculation, and nutrients [29,30]. Algae are other relevant biological entities in the green synthesis of PtNPs. Algae, primitive aquatic microorganisms, are rich in various bioactive compounds and natural reductants. Additionally, they are easily harvested, scalable, and their surfaces possess negative charges facilitating the nucleation and growth of the synthesized nanoparticles. Thus, algae can be utilized for the low-cost large-scale production and tailoring of PtNPs [31,32].

This review covers the recent trends for green synthesis of PtNPs, their characterization, and potential applications in nanomedicine. The green synthetic routes employ plant extracts and various biological entities. The influence of reaction conditions on the synthesis of PtNPs is presented, and their morphology and sizes are compared.

\section{Green Synthesis of PtNPs Utilizing Plant Extracts}

Plant extracts contain diverse primary and secondary metabolites, which could serve as natural reducing and capping agents $[13,14,33-37]$. Several studies have reported using plant extracts for green synthesis of many metallic nanoparticles (MNPs) [38-40]. The plant-mediated biosynthesis of MNPs is a simple and rapid process involving mixing the plant extract with the metal ions solution at an optimized temperature and $\mathrm{pH}$. The nanoparticle generation is indicated by the change in color of the reaction medium [41]. Various factors should be optimized to control the average size, morphology, and surface charge of MNPs, including $\mathrm{pH}$, temperature, and contact time [42-46]. Although the precise mechanisms underlying the green synthesis of MNPs using plant extracts have not been thoroughly investigated yet, a bottom-up mechanism has been proposed $[47,48]$. This proposed mechanism involves four major steps; (i) initial activation step (bio-reduction) where the metal ions are reduced into their zero-oxidation states [49], (ii) subsequent growth and agglomeration of the small nanoparticles into more substantial and more thermodynamically stable particles, (iii) termination, where stabilization and capping of the MNPs are performed to form nanoparticles of diverse morphologies and average sizes [49,50] and (iv) purification and washing of the MNPs usually by centrifugation [50].

The average sizes, morphologies, and crystallinity of the synthesized nanoparticles are optimized via controlling the reaction conditions, including $\mathrm{pH}$, temperature, and contact time [51,52]. In addition, different analytical tools were utilized to characterize the fabricated MNPs in general and PtNPs in specific, including UV/Vis spectrophotometry, dynamic light scattering (DLS), scanning electron microscopy (SEM), transmission electron microscopy (TEM), Fourier transform infrared spectroscopy (FTIR), and powder X-ray diffraction (XRD) [53-60]. Figure 1 demonstrates the plant species used for the green synthesis of PtNPs. 


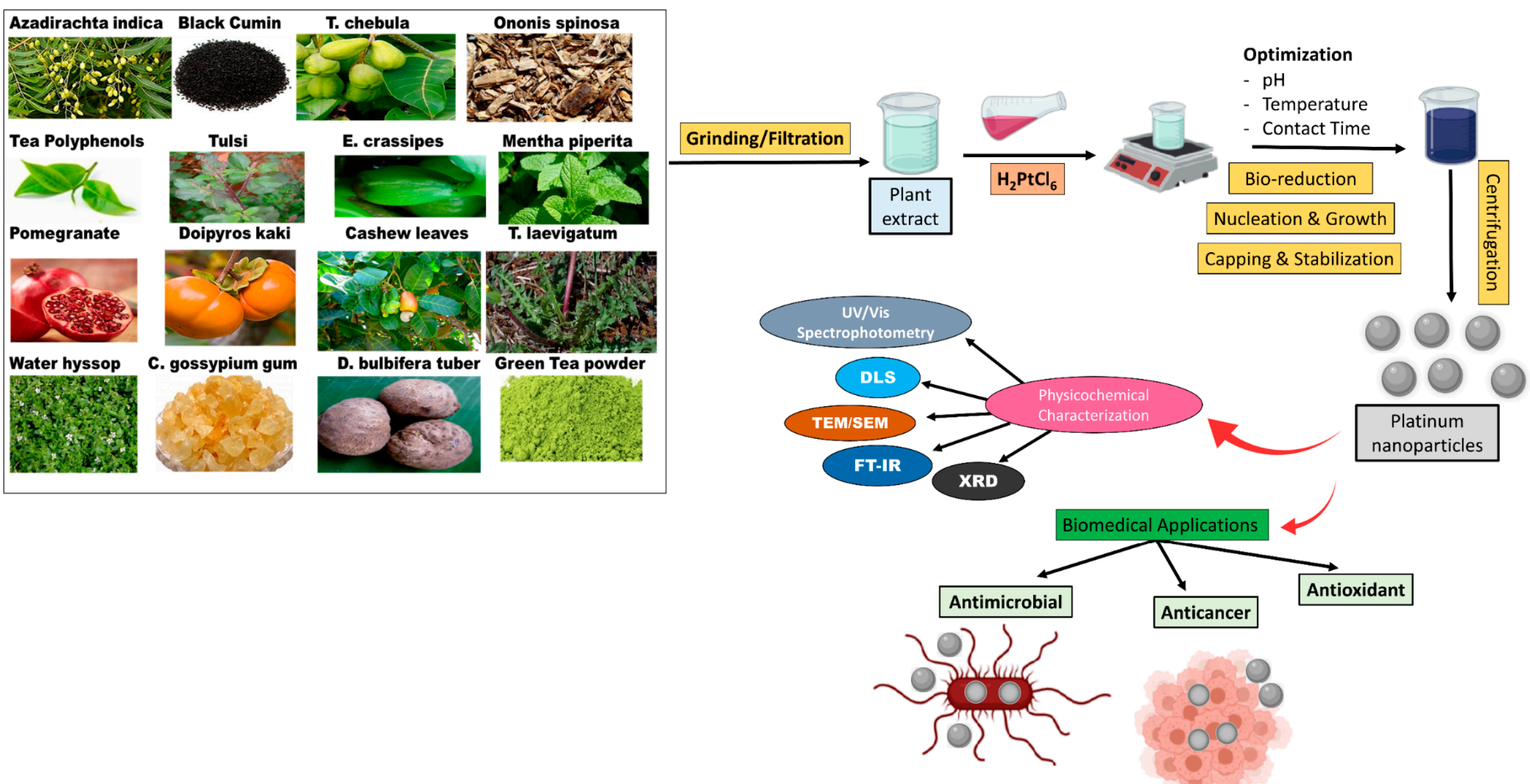

Figure 1. Schematic diagram summarizing the plant species employed in the bio-reduction of PtNPs, parameters optimized, and the techniques employed for characterization of the synthesized nanoparticles. 


\subsection{Green Synthesis of PtNPs Using Plant Extracts}

Plant extracts have been considered a green route and a reliable approach for safe, eco-friendly, and biocompatible PtNPs. The phytosynthesis of PtNPs has been used to replace the current multi-step hazardous synthetic methods. Few studies reported the use of green approaches involving plants and plant extracts. In one study, Azadirachta indica leaf broth was incubated with $\mathrm{Pt}(\mathrm{IV})$ ions for $1 \mathrm{~h}$ at $100^{\circ} \mathrm{C}$. The terpenoids of the Azadirachta indica leaf acted as the reducing and capping agents. The generated PtNPs were sonicated for 30 min to enhance the monodispersity of the NPs [61] (Table 1). A recent study reported on the phytosynthesis of PtNPs using Nigella sativa (black cumin) seed extract. Pt(IV) ions were stirred with the black cumin extract for two days at $200 \mathrm{rpm}$ and $75^{\circ} \mathrm{C}$ [62]. Kumar et al. created a single and simple step for the biosynthesis of PtNPs, employing the fruit extract of Terminalia chebula. Many researchers have considered using Terminalia chebula in the biosynthesis of MNPs due to its abundance in nature and polyphenolic content. The reaction temperature was maintained at $100{ }^{\circ} \mathrm{C}$ for $10 \mathrm{~min}$. The reduction of $\mathrm{Pt}(\mathrm{IV})$ ions was mediated by the polyphenols present in the fruit extract [63]. 
Table 1. Green synthesis of PtNPs using plant extracts.

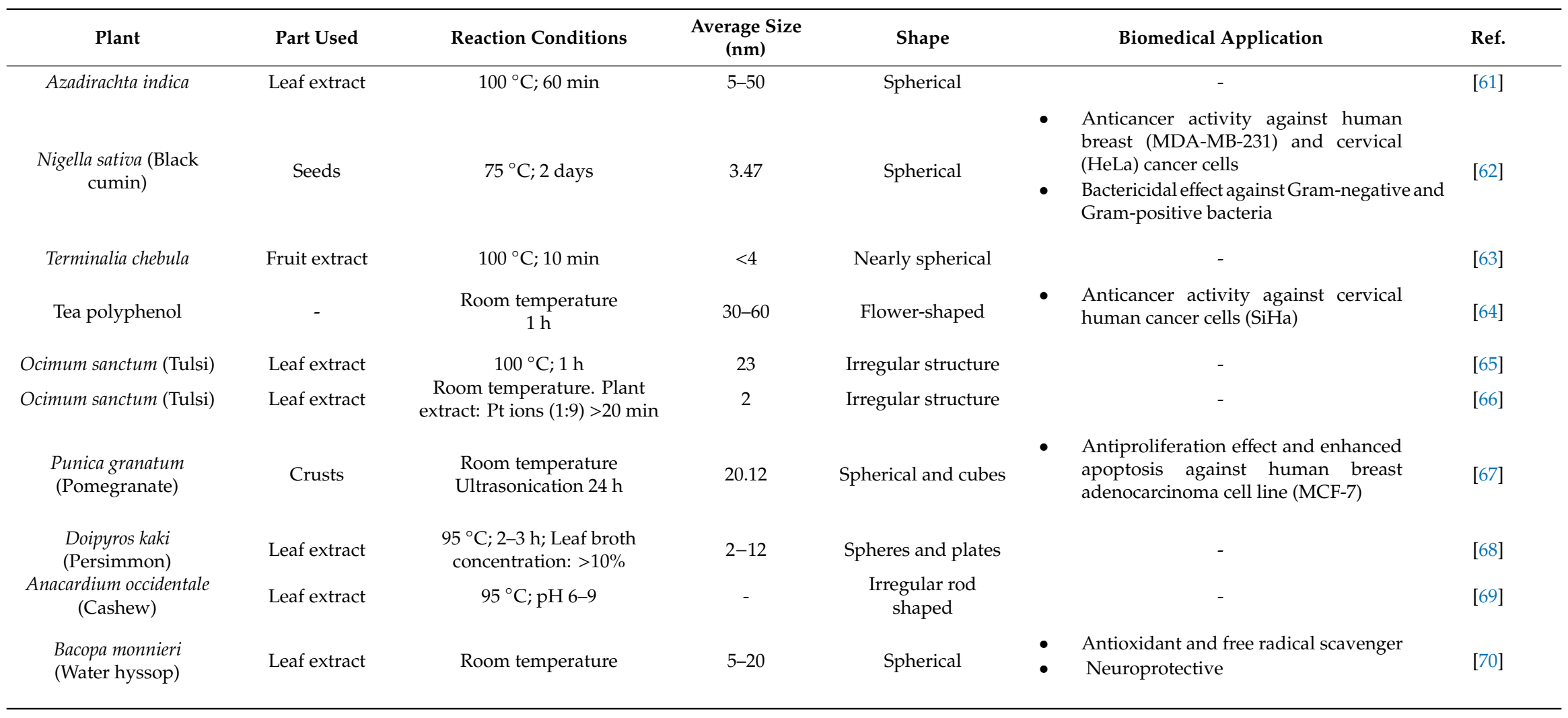


Table 1. Cont.

\begin{tabular}{|c|c|c|c|c|c|c|}
\hline Plant & Part Used & Reaction Conditions & $\begin{array}{l}\text { Average Size } \\
\text { (nm) }\end{array}$ & Shape & Biomedical Application & Ref. \\
\hline $\begin{array}{l}\text { Cochlospermum } \\
\text { gossypium }\end{array}$ & Gum & $120^{\circ} \mathrm{C} ; \mathrm{pH} 8$ & 2.4 & Spherical & - & [71] \\
\hline Dioscorea bulbifera & Tuber extract & $100^{\circ} \mathrm{C} ; 5 \mathrm{~h}$ & $2-5$ & Spherical & $\begin{array}{l}\text { - Anticancer activity against human } \\
\text { cervical (HeLa) cancer cells } \\
\text { - Antioxidant }\end{array}$ & [72] \\
\hline $\begin{array}{l}\text { Eichhornia crassipes } \\
\text { (Water hyacinth) }\end{array}$ & Leaf extract & $90^{\circ} \mathrm{C} ; 1 \mathrm{~h}$ & $\begin{array}{l}\text { TEM: } 3.74 \\
\text { DLS: } 73.3\end{array}$ & Spherical & - & [73] \\
\hline Green tea & Powder extract & $50^{\circ} \mathrm{C} ; 4 \mathrm{~h}$ & 2 & Spherical & $\begin{array}{l}\text { - Anticancer activity against two } \\
\text { human colon cancer cell lines (SW480 } \\
\text { and SW620) }\end{array}$ & [73] \\
\hline Ononis spinose & Radix extract & $80^{\circ} \mathrm{C} ; 10 \mathrm{~h}$ & 4 & $\begin{array}{l}\text { Spherical and } \\
\text { hexagonal }\end{array}$ & $\begin{array}{l}\text { - Anticancer activity against A549 cancer } \\
\text { cell lines }\end{array}$ & [74] \\
\hline Maytenus royleanus & Leaf extract & $90^{\circ} \mathrm{C} ; 3 \mathrm{~h}$ & 5 & Spherical & $\begin{array}{l}\text { - Anticancer activity against A549 cancer } \\
\text { cell lines } \\
\text { - } \quad \text { Biocompatible }\end{array}$ & [75] \\
\hline $\begin{array}{l}\text { Mentha piperita } \\
\text { (Peppermint) }\end{array}$ & Leaf extract & $60^{\circ} \mathrm{C} ; 2 \mathrm{~h}$ & 54.3 & Spherical & $\begin{array}{l}\text { - Anticancer activity against human } \\
\text { colon cancer cells (HCT116) }\end{array}$ & [76] \\
\hline Taraxacum laevigatum & Plant extract & $90^{\circ} \mathrm{C} ; 10 \mathrm{~min}$ & $2-7$ & Spherical & $\begin{array}{l}\text { - Bactericidal activity against } \\
\text { Gram-positive bacteria (Bacillus } \\
\text { subtilis) and Gram-negative bacteria } \\
\text { (Pseudomonas aeruginosa) }\end{array}$ & [77] \\
\hline Prunus $x$ yedoensis & Gum extract & $\begin{array}{c}\mathrm{pH} 8 ; \text { Gum extract } \\
\text { concentrations of } 7 \% \text { and } 8 \% \\
30 \mathrm{~min}\end{array}$ & $10-50$ & Spherical & $\begin{array}{l}\text { - Antifungal against Colletotrichum } \\
\text { acutatum and Cladosporium fulvum }\end{array}$ & [78] \\
\hline
\end{tabular}


Alshatwi et al. reported on the biosynthesis of PtNPs using tea polyphenols that act as natural reducing agents. Besides, their potential to form chelating complexes with various metal ions allowed them to be used as effective capping agents. The tea polyphenols were mixed with $\mathrm{Pt}(\mathrm{IV})$ in a ratio of 1:5 via magnetic stirring and then incubated for $1 \mathrm{~h}$ at room temperature [64].

Two studies reported the green synthesis of PtNPs using Ocimum sanctum (Tulsi) leave extract. The first synthesis was achieved at $100{ }^{\circ} \mathrm{C}$ for $1 \mathrm{~h}$ [65]. In contrast, the second one was completed at room temperature by stirring for about $20 \mathrm{~min}$, and the ratio of the plant extract to $\mathrm{Pt}(\mathrm{IV})$ ions was kept at 1:9 [66]. The phytosynthesis of PtNPs was done using ethanolic extract of (Punica granatum) pomegranate crusts as the reducing agent. Ultrasonication, involving an ultrasonic tip sonicator, was used to mix the pomegranate extract with the metal salt solution, and the mixture was magnetically stirred at room temperature for $24 \mathrm{~h}$ incubation period. Pomegranate is an up-and-coming reducing agent because it contains essential oils and resins. Additionally, pomegranate contains various therapeutically active ingredients such as alkaloids, flavonoids, and glycosides [67].

A study conducted by Song et al. reported the green synthesis of PtNPs employing the leaf extract of Diopyros kaki (Persimmon). More than $90 \%$ of the $\mathrm{Pt}(\mathrm{IV})$ ions were bio-reduced into PtNPs using $10 \%$ leaf broth concentration at $95^{\circ} \mathrm{C}$ for $2-3 \mathrm{~h}$ [68]. Sheny et al. biosynthesized PtNPs by mixing dried leaf powder of Anacardium occidentale (Cashew) with $\mathrm{Pt}(\mathrm{IV})$ ions at $95{ }^{\circ} \mathrm{C}$ and $\mathrm{pH}$ range $6-9$, and the bioreduction reaction was immediate [69]. PtNPs were prepared using the leaf extract of Bacopa monnieri (Water hyssop), which was mixed with $\mathrm{Pt}(\mathrm{IV})$ ions in a ratio of 1:4 at room temperature [70].

Vinod et al. obtained PtNPs Cochlospermum gossypium gum mixed with the metal ions solution at $120^{\circ} \mathrm{C}$ using an autoclave (15 psi) and pH 8. This is the only study we found that involved autoclave use to achieve the rapid biosynthesis of PtNPs. Heating and adjusting the $\mathrm{pH}$ were involved in activating the glucose, a mild reducing agent, present in the gum extract to achieve controllable bioreduction kinetics [71]. Ghosh et al. employed the tuber extract of Dioscorea bulbifera in biosynthesizing PtNPs by conducting the bio-reaction at $100^{\circ} \mathrm{C}$ for $5 \mathrm{~h}$ [72]. A recent study by Anyik et al. reported the synthesis of PtNPs using the leaf extract of Eichhornia crassipes (Water hyacinth). The reaction was carried out at $100{ }^{\circ} \mathrm{C}$ for $1 \mathrm{~h}$ [79]. In a recent study, PtNPs were biosynthesized by mixing green tea powder extract with $\mathrm{Pt}$ (II) ions for $4 \mathrm{~h}$ using a magnetic stirrer at $50^{\circ} \mathrm{C}$. The flavonoids present in green tea played a significant role in the bioreduction of $\mathrm{Pt}(\mathrm{IV})$ ions owing to their hydroxyl groups [73].

Dobrucka et al. reported on the green synthesis of PtNPs employing Ononis spinosa radix extract. Patient ions' reaction was maintained at $80{ }^{\circ} \mathrm{C}$ for $10 \mathrm{~h}$ with continuous stirring [74]. Ullah et al. reported the green synthesis of PtNPs utilizing leaf extract of Maytenus royleanus. The flavonoids and phenolic compounds present in the leaf extract are responsible for reducing Pt(IV) ions into PtNPs. The reaction temperature was maintained at $90{ }^{\circ} \mathrm{C}$ for $3 \mathrm{~h}$ with continuous stirring [75].

Yang et al. used the leaf extract of Mentha piperita (Peppermint) in biosynthesizing spherical PtNPs by conducting the bio-reduction at $60{ }^{\circ} \mathrm{C}$ for $90 \mathrm{~min}$ [76]. Tahir et al. developed a facile method for the biosynthesis of spherical PtNPs, employing the plant extract of Taraxacum laevigatum. Bioreduction was carried out at $90^{\circ} \mathrm{C}$ for $10 \mathrm{~min}$ [77]. Finally, eco-friendly PtNPs were fabricated using gum extract of Prunus $x$ yedoensis. The reaction conditions were optimized at $\mathrm{pH} 8$ and gum extract concentrations of $7 \%$ and $8 \%$ for $30 \mathrm{~min}[78]$.

\subsection{Characterization and Biological Activities of PtNPs Prepared Using Plant Extracts}

Various analytical tools are utilized in the characterization of PtNPs such as Fourier transform infrared spectroscopy (FT-IR), X-ray diffraction (XRD), transmission electron microscopy (TEM), scanning electron microscopy (SEM), dynamic lights scattering (DLS), and thermal gravimetric analysis (TGA) [61-84]. However, dynamic light scattering (DLS), UV/Vis spectrophotometry, and TEM can be used for facile confirmation of the formation of PtNPs (Figure 2). 
A

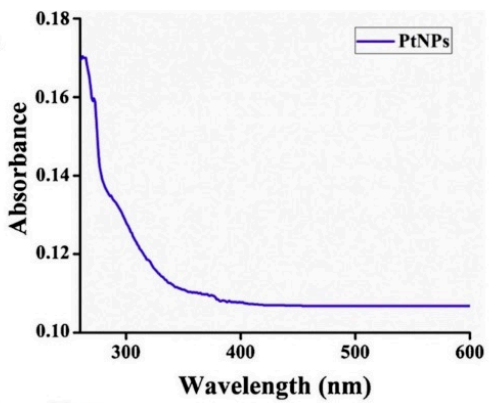

B

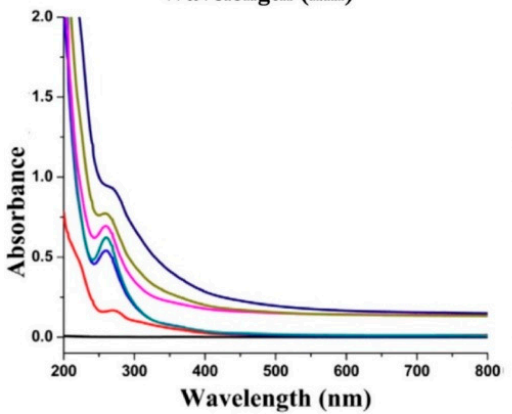

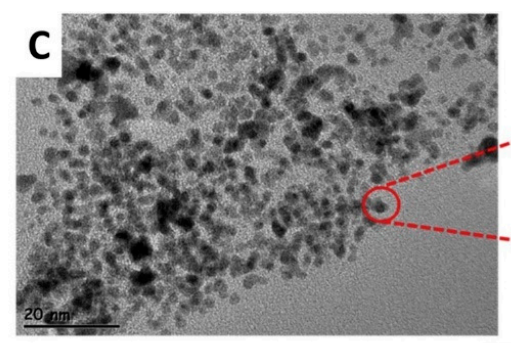
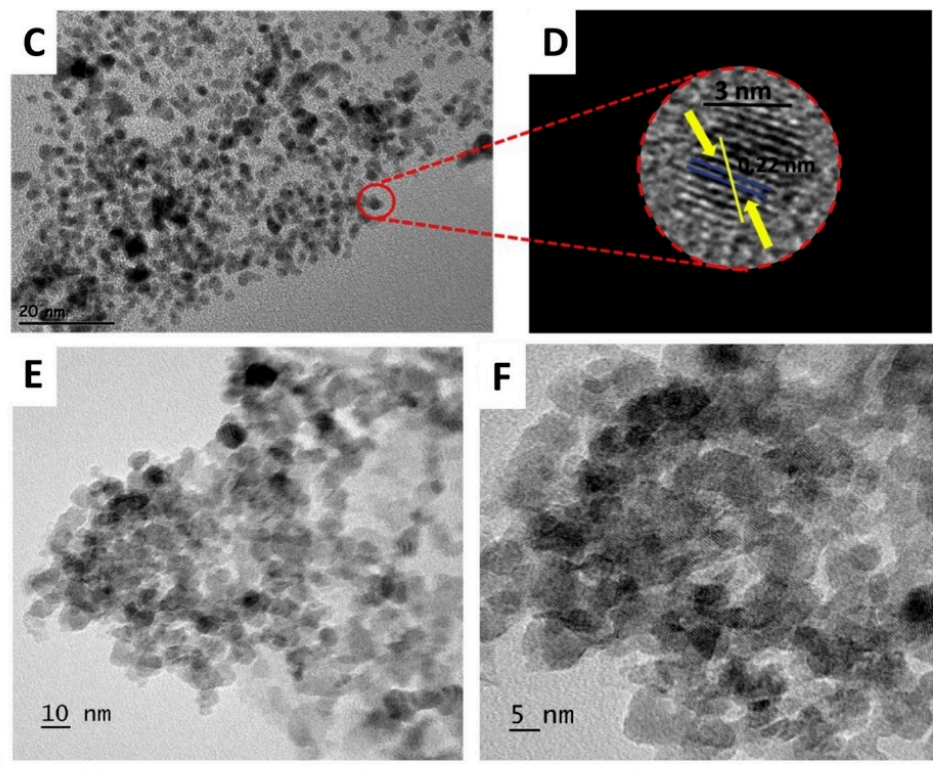

Figure 2. Characterization of PtNPs phytosynthesized utilizing plant extracts using UV/Vis spectrophotometry and TEM. (A,B) are the UV/Vis spectra of the biosynthesized PtNPs using Nigella sativa and Mentha piperita, respectively. (C,D) are the TEM and the HR-TEM images of the biosynthesized PtNPs using Nigella sativa. (E,F) are the TEM images of the biosynthesized PtNPs using Mentha piperita at a scale of 10 and $5 \mathrm{~nm}$, respectively [62,76].

The formation of Azadirachta indica mediated PtNPs was confirmed qualitatively by converting the initial light-yellow color into black, and quantitatively by UV/Vis spectrophotometry. A strong surface Plasmon resonance (SPR) absorption band at $241 \mathrm{~nm}$ indicated the formation of the reduced PtNPs. TEM investigations indicated the production of small to large spherical nanoparticles in a size range of 5-50 $\mathrm{nm}$ [61].

The PtNPs generated using Nigella sativa (black cumin) seed extract were shown to have a spherical shape and an average size of $3.47 \mathrm{~nm}$. Additionally, the formation of PtNPs was confirmed by the appearance of a significant SPR peak at $263 \mathrm{~nm}$ (Figure 2A,C,D). The biosynthesized PtNPs were found to have significant anticancer activity against human breast (MDA-MB-231) and cervical (HeLa) cancer cells ( $\mathrm{IC}_{50}: 36.86 \mu \mathrm{g} / \mathrm{mL}$ and $19.83 \mu \mathrm{g} / \mathrm{mL}$; respectively). In addition, the produced NPs showed a pronounced bactericidal activity against Gram-negative and Gram-positive bacteria at concentrations of $100 \mu \mathrm{g}$ and $500 \mu \mathrm{g} / \mathrm{mL}$ [62].

The Terminalia chebula mediated PtNPs were spherical, having an average size of $<4 \mathrm{~nm}$. Besides, the disappearance of the UV/Vis absorption band at $262 \mathrm{~nm}$ corresponding to $\mathrm{Pt}(\mathrm{IV})$ ions suggested the reduction of $\mathrm{Pt}(\mathrm{IV})$ ions [63].

PtNPs prepared using tea polyphenols had flower-shaped morphology and an average size of 30 to $60 \mathrm{~nm}$. In addition, the biosynthesized PtNPs had potent cytotoxic activity, attributed to induction of apoptosis, against cervical human cancer cells (SiHa). The $\mathrm{IC}_{50}$ and $\mathrm{IC}_{75}$ were $18.34 \mu \mathrm{g} / \mathrm{mL}$ and $11.4 \mu \mathrm{g} / \mathrm{mL}$, respectively [64].

Two studies reported the green synthesis of PtNPs using Ocimum sanctum (Tulsi) leaves extract yielding irregular structured NPs with sizes 23 and $2 \mathrm{~nm}$, respectively $[65,66]$. PtNPs were characterized by FT-IR, XRD, energy dispersive absorption X-Ray, SEM, and TEM. Additionally, the UV/Vis spectrophotometry was involved as an extra tool to confirm the production of PtNPs. An absorption band was observed at $400 \mathrm{~nm}$, which indicated the formation of PtNPs [66].

The phytosynthesis of monodispersed spherical and cubical PtNPs with an average size of $20 \mathrm{~nm}$ was done using ethanolic extract of (Punica granatum) pomegranate crusts. The biosynthesized PtNPs 
were found to have significant cytotoxicity against MCF-7 cancer cells with an $\mathrm{IC}_{50}$ of $17.84 \mu \mathrm{g} / \mathrm{mL}$ after $48 \mathrm{~h}$ of incubation [67].

PtNPs biosynthesized utilizing the leaf extract of Diopyros kaki (Persimmon) had a size range of 2-12 nm. Furthermore, a UV/Vis absorption band was observed at $477 \mathrm{~nm}$, which increased with increasing the Pt concentration, indicating the generation of PtNPs [68]. PtNPs prepared using Anacardium occidentale (Cashew) showed irregular rod-shaped morphology. The synthesis of PtNPs was confirmed by the disappearance of the UV/Vis absorption band at $259 \mathrm{~nm}$, corresponding to $\mathrm{Pt}(\mathrm{IV})$ ions, and the observation of a continuum at $200 \mathrm{~nm}$ suggested the reduction of $\mathrm{Pt}(\mathrm{IV})$ ions and the formation of PtNPs. The UV/Vis data showed that the absorbance increases by increasing the quantity of dried leaf powder and decreasing $\mathrm{pH}$ [69].

Spherical PtNPs, 5-20 nm, were prepared using the leaf extract of Bacopa monnieri (Water hyssop). The formation of the PtNPs was confirmed by the appearance of a UV/Vis absorbance band at 330-380 nm. The biosynthesized nanoparticles were found to have pronounced antioxidant and neuroprotective activities, making them promising candidates for the potential treatment of Parkinson's disease [70].

Vinod et al. obtained spherical PtNPs of $2.4 \mathrm{~nm}$ size using Cochlospermum gossypium gum [71]. Ghosh et al. used the tuber extract of Dioscorea bulbifera in biosynthesizing spherical PtNPs $(2-5 \mathrm{~nm})$. The generated nanoparticles exhibited anticancer activity against human cervical (HeLa) cancer cells. Besides, PtNPs showed antioxidant and pronounced free radical scavenging activity when tested using 2,2-diphenyl-1-picrylhydrazyl, superoxide, nitric oxide, and hydroxyl radicals [72].

The DLS and TEM sizes of the Eichhornia crassipes mediated PtNPs were 73.3 and $3.74 \mathrm{~nm}$, respectively, with spherical shapes (it is of note that TEM measures the actual diameter of the PtNPs while DLS measures the diameter in the hydrated state). The disappearance of the UV/Vis absorption band observed at $261 \mathrm{~nm}$ corresponding to $\mathrm{Pt}(\mathrm{IV})$ ions and the observation of a continuum at 200-300 nm suggested the generation of PtNPs [79]. In another study, the photothermal properties of green tea mediated PtNPs were exploited in cancer therapy. The synthesized PtNPs were found to have a spherical morphology and an average size of $2 \mathrm{~nm}$. The disappearance of the bio-reducer's absorption band at $320 \mathrm{~nm}$ suggested the involvement of the bio-reducer, present in green tea, in reduction of $\mathrm{Pt}(\mathrm{IV})$ ions into $\mathrm{Pt}^{\mathrm{O}}$.

Additionally, the appearance of UV bands in the range of 270-280 suggested the formation of PtNPs. Two human colon cancer cell lines (SW480 and SW620) were used to investigate the anticancer activity of the biosynthesized PtNPs combined with photothermal treatment for 5 min using low-intensity lasers operating at 650 and $808 \mathrm{~nm}$. High cytotoxicity was observed for the biosynthesized PtNPs combined with laser irradiation. The \% viability of cancer cells cultured with PtNPs and irradiated with $650 \mathrm{~nm}$ laser was found to be $21 \%$ and $18 \%$ for SW480 and SW620, respectively. While the \% viability for cancer cells cultured with PtNPs and irradiated with $808 \mathrm{~nm}$ laser was $25 \%$ and $22 \%$ for SW480 and SW620, respectively. These findings may support future applications of biosynthesized PtNPs in photothermal cancer therapy [73].

Dobrucka et al. reported the green synthesis of spherical and hexagonal PtNPs $(4 \mathrm{~nm})$ employing Ononis spinosa radix extract. The anticancer activity of the biosynthesized PtNPs was evaluated against A549 cancer cell lines. The maximum cell mortality of $8.8 \%$ was observed at an incubation time of $72 \mathrm{~h}$ and a concentration of $100 \mu \mathrm{g} / \mathrm{mL}$ of PtNPs [74]. Ullah et al. reported the synthesis of spherical PtNPs of size $5 \mathrm{~nm}$ utilizing leaf extract of Maytenus royleanus. The appearance of the UV/Vis absorption SPR band at $282 \mathrm{~nm}$ suggested the generation of PtNPs. The cytotoxic activity of the prepared PtNPs was evaluated against the A549 cancer cell line. Exposure of A549 cancer cells to increasing concentrations of PtNPs for $24 \mathrm{~h}$ has resulted in reduced cell viability, damage to cellular morphology, and reduction in cell number in a dose-dependent manner [75]. Additionally, the PtNPs were found to be biocompatible with normal cells. These findings support the possible development of potent and selective anticancer drugs at low cost [75]. 
Yang et al. used the leaf extract of Mentha piperita (Peppermint) in biosynthesizing spherical PtNPs $(54 \mathrm{~nm})$ with surface charge of $-50.1 \mathrm{mV}$, indicating high stability. The appearance of a UV/Vis absorption band at $272 \mathrm{~nm}$ indicated the formation of the PtNPs (Figure 2B,E,F). The anticancer activity of the biosynthesized PtNPs was tested against the human colon cancer cell line (HCT116). PtNPs reduced tumor cells' viability at lower concentrations with an $\mathrm{IC}_{50}$ value of $20 \mu \mathrm{g} / \mathrm{mL}$ [76]. The PtNPs created by Tahir et al. employing the plant extract of Taraxacum laevigatum were spherical in size range of 2-7 nm. The UV/Vis absorption band's appearance at $283 \mathrm{~nm}$ suggested the formation of PtNPs [77]. The bactericidal activity of the greenly synthesized PtNPs was evaluated against Gram-positive bacteria (Bacillus subtilis) and Gram-negative bacteria (Pseudomonas aeruginosa). The findings revealed that the PtNPs exhibited significant antibacterial activity against both strains (zones of inhibitions were $15( \pm 0.5) \mathrm{mm}$ and $18( \pm 0.8) \mathrm{mm}$ for P. aeruginosa and B. subtilis, respectively), making them promising antibiotics that could overcome bacterial resistance [77]. Finally, spherical PtNPs (10-50 nm) were fabricated using gum extract of Prunus $x$ yedoensis. The appearance of the UV/Vis absorption band at $277 \mathrm{~nm}$ suggested the creation of the PtNPs. The antifungal activity of the biosynthesized PtNPs was investigated against Colletotrichum acutatum and Cladosporium fulvum exhibiting $15 \mathrm{~mm}$ and $18 \mathrm{~mm}$ zones of inhibition at concentrations of 4 and $8 \mu \mathrm{g} /$ well, respectively [78].

\section{Green Synthesis of PtNPs Using Miscellaneous Biological Entities}

Few studies have reported the synthesis of PtNPs utilizing biological entities other than plants (Table 2). In one study, quail egg yolk, containing peroxidase as a reducing agent, was mixed with $\mathrm{Pt}(\mathrm{IV})$ ions and then stirred at $100 \mathrm{rpm}$ for $4 \mathrm{~h}$ at $20^{\circ} \mathrm{C}$ and pH 6 [80]. The temperature was kept at $20{ }^{\circ} \mathrm{C}$ to avoid protein denaturation. The formation of the PtNPs $(7-50 \mathrm{~nm})$ was confirmed by the appearance of a sharp UV/Vis peak at $329 \mathrm{~nm}$ [80].

Table 2. Biosynthesis of PtNPs using various biological entities.

\begin{tabular}{|c|c|c|c|c|c|}
\hline Biological Entity & $\begin{array}{l}\text { Reaction } \\
\text { Conditions }\end{array}$ & $\begin{array}{l}\text { Average } \\
\text { Size (nm) }\end{array}$ & Shape & Biomedical Application & Ref. \\
\hline Quail egg yolk & $20^{\circ} \mathrm{C} ; \mathrm{pH} 6 ; 4 \mathrm{~h}$ & $7-50$ & Spherical & - & [80] \\
\hline $\begin{array}{l}\text { Streptomyces species } \\
\text { (Gram-positive } \\
\text { bacteria)) }\end{array}$ & $50{ }^{\circ} \mathrm{C} ; 24 \mathrm{~h}$ & $20-50$ & Spherical & $\begin{array}{l}\text { - Anticancer activity } \\
\text { against human breast } \\
\text { cancer cell lines } \\
\text { (MCF-7) }\end{array}$ & [81] \\
\hline $\begin{array}{c}\text { Acinetobacter } \\
\text { calcoaceticus bacteria }\end{array}$ & $\begin{array}{c}30^{\circ} \mathrm{C} ; \mathrm{pH} 7 ; 24 \mathrm{~h} \\
\text { room }\end{array}$ & $2-3.5$ & Cuboidal & - & [82] \\
\hline Sheep milk & $\begin{array}{l}\text { temperature for } \\
3 \mathrm{~h} .\end{array}$ & 9 & Spherical & - & [83] \\
\hline Honey & $\begin{array}{c}100{ }^{\circ} \mathrm{C} \text { for } 2 \text { and } \\
4 \mathrm{~h}\end{array}$ & 2.2 & Nanowires & - & [84] \\
\hline $\begin{array}{c}\text { Globular protein } \\
\text { bovine serum albumin } \\
\text { (BSA) }\end{array}$ & $\begin{array}{c}37^{\circ} \mathrm{C} ; \mathrm{pH} 3.2 \text { for } \\
24 \mathrm{~h}\end{array}$ & $10-30$ & Spherical & - & [85] \\
\hline $\begin{array}{l}\text { Padina gymnospora } \\
\text { (brown algae) }\end{array}$ & $\begin{array}{l}\text { room } \\
\text { temperature for } \\
10 \mathrm{~min}\end{array}$ & $5-50$ & $\begin{array}{l}\text { Truncated } \\
\text { octahedral }\end{array}$ & $\begin{array}{l}\text { - Bactericidal activity } \\
\text { against Escherichia coli, } \\
\text { Lactococcus lactis, and } \\
\text { Klebsiella pneumoniae }\end{array}$ & [86] \\
\hline $\begin{array}{l}\text { Padina gymnospora } \\
\text { (brown algae) }\end{array}$ & $50^{\circ} \mathrm{C} ; 3 \mathrm{~h}$ & $20-35$ & Spherical & $\begin{array}{l}\text { - Anticancer activity } \\
\text { against A549 lung } \\
\text { carcinoma cells }\end{array}$ & [87] \\
\hline $\begin{array}{l}\text { Fusarium oxysporum } \\
\text { fungus }\end{array}$ & $\begin{array}{c}\text { Room } \\
\text { temperature for } \\
96 \mathrm{~h}\end{array}$ & $15-30$ & Spherical & - & [88] \\
\hline
\end{tabular}


Another study exploited Streptomyces bacterial strains for the green synthesis of PtNPs. The PtNPs were generated by incubating the bacterial strain with $\mathrm{Pt}(\mathrm{IV})$ ions at $50{ }^{\circ} \mathrm{C}$ for $24 \mathrm{~h}$. The bio-reduction of the PtNPs was proposed to be mediated by NAD-dependent chloride reductase (the electron shuttle enzymatic metal reduction process). The formation of PtNPs was confirmed by the appearance of a symmetric UV/Vis peak at $262 \mathrm{~nm}$. The biosynthesized PtNPs exhibited a spherical morphology, a zeta potential of $-18.4 \mathrm{mV}$ (indicating the stability of the NPs), and a size range of 20-50 nm. The PtNPs exhibited significant cytotoxic activity against human breast cancer cell lines (MCF-7) with $\mathrm{IC}_{50}$ of $31.2 \mu \mathrm{g} / \mathrm{mL}$, which supports further investigation of the potential use of biogenic PtNPs in breast cancer therapy [81]. Acinetobacter calcoaceticus, sulfate-reducing bacteria, were involved in the green synthesis of cuboidal PtNPs in size range of $2-3.5 \mathrm{~nm}$ at $\mathrm{pH} 7.0$, reaction temperature of $30^{\circ} \mathrm{C}$, and contact time of $24 \mathrm{~h}$ [82].

Sheep milk was utilized for the rapid and eco-friendly biosynthesis of spherical PtNPs of an average size of $9 \mathrm{~nm}$ and zeta potential of $-31 \mathrm{mV}$. The sheep milk was mixed with $\mathrm{Pt}(\mathrm{IV})$ ions and incubated in a rotary shaker $(200 \mathrm{rpm})$ at room temperature for $3 \mathrm{~h}$. The bio-reduction of $\mathrm{Pt}(\mathrm{IV})$ ions and the formation of PtNPs was confirmed by the appearance of the UV/Vis peak in the range of 278-284 nm [83]. Highly crystalline Pt nanowires of average size of $2.2 \mathrm{~nm}$ were biosynthesized, employing aqueous honey solutions at $100{ }^{\circ} \mathrm{C}$ for 2 and $4 \mathrm{~h}$ [84]. The globular protein bovine serum albumin (BSA) was used in the green synthesis of spherical PtNPs in a size range of 10-30 nm. The biosynthesis was achieved by adding the $\mathrm{Pt}(\mathrm{IV})$ ions to the BSA solution under magnetic stirring at a $\mathrm{pH}$ of 3.2 and a temperature of $37^{\circ} \mathrm{C}$ for $24 \mathrm{~h}$ [85].

Two studies reported on the green synthesis of PtNPs using the aqueous extract of the Indian brown seaweed Padina gymnospora yielding truncated octahedral and spherical PtNPs with sizes range 5-50 and 20-35 nm, respectively [86,87]. The first green synthesis was achieved by vigorous stirring at room temperature for $10 \mathrm{~min}$ [86], while the second was completed after $3 \mathrm{~h}$ incubation at $50{ }^{\circ} \mathrm{C}$ [87]. Both studies, PtNPs were characterized using FT-IR, XRD, Energy Dispersive X-ray spectroscopy, SEM, and TEM. In the first study, the disappearance of the peak at $320 \mathrm{~nm}$ suggested the formation of PtNPs [86]. The truncated octahedral PtNPs showed maximum bactericidal activity against Escherichia coli (15.6 $\mathrm{mm}$, the zone of inhibition), Lactococcus lactis (14.8 $\mathrm{mm}$, the zone of inhibition), and Klebsiella pneumoniae (14.4 mm, the zone of inhibition) [86]. They were found biocompatible to red blood cells with no observed hemolytic activity [86]. The spherical PtNPs had anticancer activity against $\mathrm{A} 549$ lung carcinoma cells with $\mathrm{IC}_{50}$ of $19.3 \mu \mathrm{g} / \mathrm{mL}$ and remarkable cytotoxicity [87].

Finally, the fungus Fusarium oxysporum was utilized in the green synthesis of spherical PtNPs in the size range of 15-30 nm by shaking the fungal extract with $\mathrm{Pt}(\mathrm{IV})$ ions at $200 \mathrm{rpm}$ for $96 \mathrm{~h}$ at room temperature [88]. Table 3 summarizes the UV/Vis absorption parameters of the PtNPs biosynthesized using different biological sources.

Green synthesis of PtNPs using different biological systems is affected by critical parameters such as temperature, reaction time, the ratio of metal ions to plant extract, and $\mathrm{pH}$. These parameters control the rate and yield of the PtNPs, their size, shape, and stability. For instance, the biosynthesis rate of Azardica Indica mediated PtNPs was directly proportional to the reaction temperature [61]. At a reaction temperature of $25^{\circ} \mathrm{C}$, only $20 \%$ of $\mathrm{Pt}(\mathrm{IV})$ ions were reduced into PtNPs using Doipyros kaki, while at a temperature of $95^{\circ} \mathrm{C}, 100 \%$ of $\mathrm{Pt}(\mathrm{IV})$ ions were reduced. Additionally, the biosynthesis rate increased with increasing the Doipyros kaki leaf extract concentration where $10 \%$ and $100 \%$ of PtNPs were formed at leaf concentrations of 5\% and 10\%, respectively. Additionally, increasing the biosynthesis's reaction temperature from $25^{\circ} \mathrm{C}$ to $95^{\circ} \mathrm{C}$ has decreased the size of PtNPs from 12 to $5 \mathrm{~nm}$ [68]. Velmurugan et al. found that higher yields of PtNPs were achieved at Prunus $x$ yedoensis gum extract concentrations of $7 \%$ and $10 \%$. Adjusting the reaction $\mathrm{pH}$ is an important factor in increasing both the stability and yield of synthesized PtNPs. For instance, the stability and the UV-Vis absorbance in the Anacardium occidentale mediated PtNPs were increased at a pH range of 6-8 [69]. Size optimization of PtNPs is a crucial factor that significantly influences the clinical use of PtNPs in various biomedical applications. PtNPs with an average size of $8 \mathrm{~nm}$ exhibited negligible systemic adverse effects, while those with an average 
size of $1 \mathrm{~nm}$ possessed toxic effects against renal cells in a dose-dependent manner. Another study reported the cytocompatibility of PtNPs to the Neuro 2 cell line, while other sizes caused remarkable neurotoxicity. Simultaneously, a study conducted by Konieczny et al. reported the safety of PtNPs with an average size of $57 \mathrm{~nm}$ to keratinocytes compared to smaller sizes [89,90].

Table 3. UV/Vis absorption bands for the PtNPs synthesized using various biological entities.

\begin{tabular}{|c|c|c|c|}
\hline Plant & Peak Appeared (nm) & Peak Disappeared (nm) & Reference \\
\hline Azadirachta indica & $241 *$ & - & [61] \\
\hline Nigella sativa & 263 & - & [62] \\
\hline Terminalia chebula & - & $262 * *$ & {$[63]$} \\
\hline Ocimum sanctum (Tulsi) & 400 & - & {$[66]$} \\
\hline $\begin{array}{l}\text { Doipyros kaki } \\
\text { (Persimmon) }\end{array}$ & 477 & - & [68] \\
\hline $\begin{array}{c}\text { Anacardium occidentale } \\
\text { (Cashew) }\end{array}$ & 200 & $259 * *$ & [69] \\
\hline $\begin{array}{l}\text { Bacopa monnieri } \\
\text { (Water hyssop) }\end{array}$ & $330-380$ & - & [70] \\
\hline $\begin{array}{l}\text { Eichhornia crassipes } \\
\text { (Water hyacinth) }\end{array}$ & 200-300 (continuum) & $261^{* *}$ & [79] \\
\hline Green tea powder extract & - & $320 * * *$ & [73] \\
\hline Ononis spinosa & $\begin{array}{l}200-300 \text { (broad } \\
\text { continuum) }\end{array}$ & 265 & [74] \\
\hline Maytenus royleanus & 282 & - & [75] \\
\hline Mentha piperita & 272 & - & [76] \\
\hline Taraxacum laevigatum & 283 & - & [77] \\
\hline Prunus $x$ yedoensis & 277 & - & [78] \\
\hline Quail egg yolk & 329 & - & [80] \\
\hline Padina gymnospora & - & 320 & [81] \\
\hline Streptomyces species & 262 & - & [83] \\
\hline Sheep milk & $278-284$ & - & [84] \\
\hline
\end{tabular}

${ }^{*}$ Indicate the formation of the reduced PtNPs. ${ }^{* *}$ Corresponding to Pt(IV) ions. ${ }^{* * *}$ Corresponding to the bio-reducer within the green tea.

\section{Conclusions and Future Directions}

In this review, state-of-the-art studies for green synthesis of PtNPs using various biological entities, including plant extracts, algae, microorganisms, egg yolk, sheep milk, and bovine serum albumin are presented. The green synthesis is mainly conducted under ambient conditions and short reaction times. Critical parameters such as temperature, contact time, rate of adding biological entities, and $\mathrm{pH}$ must be optimized during the biosynthesis to control the average size and shape of the PtNPs, which will influence their possible use in various biomedical applications. Plants and other biological entities are also rich in different bioactive compounds, which may be deposited onto the PtNPs during synthesis. PtNPs capped with bioactive compounds could be used as promising antibacterial, anticancer, and antifungal agents. Despite the endeavors to develop biosynthesized PtNPs for potential use in nanomedicine, many challenges still exist. As for other MNPs, additional in vitro and animal studies are needed to understand clearance mechanisms of biosynthesized PtNPs, their influence on the immune system and antioxidant activity, and other long-term effects.

Author Contributions: Conceptualization, S.A.F., U.B., and H.M.E.-S.A.; methodology, S.A.F. and E.P.; data curation, S.A.F. and H.M.E.-S.A.; writing—original draft preparation, S.A.F.; writing-review and editing, S.A.F., E.P., U.B. and H.M.E.-S.A.; supervision, U.B. and H.M.E.-S.A.; project administration, U.B. and H.M.E.-S.A. All authors have read and agreed to the published version of the manuscript.

Funding: This research received no external funding.

Conflicts of Interest: The authors declare no conflict of interest. 


\section{References}

1. Dreaden, E.C.; Alkilany, A.M.; Huang, X.; Murphy, C.J.; El-Sayed, M.A. The golden age: Gold nanoparticles for biomedicine. Chem. Soc. Rev. 2012, 41, 2740-2779. [CrossRef] [PubMed]

2. Gurunathan, S.; Jeyaraj, M.; Kang, M.-H.; Kim, J.-H. Tangeretin-Assisted Platinum Nanoparticles Enhance the Apoptotic Properties of Doxorubicin: Combination Therapy for Osteosarcoma Treatment. Nanomaterials 2019, 9, 1089. [CrossRef] [PubMed]

3. Sadrolhosseini, A.R.; Habibiasr, M.; Shafie, S.; Solaimani, H.; Lim, H.N. Optical and Thermal Properties of Laser-Ablated Platinum Nanoparticles Graphene Oxide Composite. Int. J. Mol. Sci. 2019, 20, 6153. [CrossRef] [PubMed]

4. Khan, I.; Saeed, K.; Khan, I. Nanoparticles: Properties, applications and toxicities. Arab. J. Chem. 2019, 12, 908-931. [CrossRef]

5. Nugroho, F.A.A.; Iandolo, B.; Wagner, J.B.; Langhammer, C. Bottom-up nanofabrication of supported noble metal alloy nanoparticle arrays for plasmonics. ACS Nano 2016, 10, 2871-2879. [CrossRef] [PubMed]

6. Jeyaraj, M.; Gurunathan, S.; Qasim, M.; Kang, M.-H.; Kim, J.-H. A Comprehensive Review on the Synthesis, Characterization, and Biomedical Application of Platinum Nanoparticles. Nanomaterials 2019, 9, 1719. [CrossRef] [PubMed]

7. Jain, N.; Bhargava, A.; Majumdar, S.; Panwar, J. Extracellular biosynthesis and characterization of silver nanoparticles using Aspergillus flavus NJP08: A mechanism prospective. Nanoscale 2011, 3, 635-641. [CrossRef] [PubMed]

8. Mittal, A.K.; Chisti, Y.; Banerjee, U.C. Synthesis of metallic nanoparticles using plants. Biotechnol. Adv. 2013, 31, 346-356. [CrossRef]

9. Salem, S.S.; Fouda, A. Green Synthesis of Metallic Nanoparticles and Their Prospective Biotechnological Applications: An Overview. Biol. Trace Elem. Res. 2020. [CrossRef]

10. Fahmy, S.A.; Mamdouh, W. Garlic oil-loaded PLGA nanoparticles with controllable Size and shape and enhanced antibacterial activities. J. Appl. Polym. Sci. 2018, 135, 46133. [CrossRef]

11. Vijilvani, C.; Bindhu, M.R.; Frincy, F.C.; AlSalhi Mohamad, S.; Sabitha, S.; Saravanakumar, K.; Devanesan, S.; Umadevi, M.; Aljaafreh Mamduh, J.; Atif, M. Antimicrobial and catalytic activities of biosynthesized gold, silver and palladium nanoparticles from Solanum nigurum leaves. J. Photochem. Photobiol. B Biol. 2020, 202, 111713. [CrossRef] [PubMed]

12. Gan, P.P. Potential of plant as a biological factory to synthesize gold and silver nanoparticles and their applications. Rev. Environ. Sci. Biotechnol. 2012, 11, 169-206. [CrossRef]

13. Castillo-Henríquez, L.; Alfaro-Aguilar, K.; Ugalde-Álvarez, J.; Vega-Fernández, L.; Montes de Oca-Vásquez, G.; Vega-Baudrit, J.R. Green Synthesis of Gold and Silver Nanoparticles from Plant Extracts and Their Possible Applications as Antimicrobial Agents in the Agricultural Area. Nanomaterials 2020, 10, 1763. [CrossRef]

14. Puja, P.; Kumar, P. A perspective on biogenic synthesis of platinum nanoparticles and their biomedical applications. Spectrochim. Acta A 2019, 211, 94-99. [CrossRef] [PubMed]

15. Singh, A.; Gautam, P.K.; Verma, A.; Singh, V.; Shivapriya, P.M.; Shivalkar, S.; Sahoo, A.K.; Samanta, S.K. Green synthesis of metallic nanoparticles as effective alternatives to treat antibiotics resistant bacterial infections: A review. Biotechnol. Rep. 2020, 25, e00427. [CrossRef] [PubMed]

16. Elgamouz, A.; Idriss, H.; Nassab, C.; Bihi, A.; Bajou, K.; Hasan, K.; Abu Haija, M.; Patole, S.P. Green Synthesis, Characterization, Antimicrobial, Anti-Cancer, and Optimization of Colorimetric Sensing of Hydrogen Peroxide of Algae Extract Capped Silver Nanoparticles. Nanomaterials 2020, 10, 1861. [CrossRef]

17. Kato, Y.; Suzuki, M. Synthesis of Metal Nanoparticles by Microorganisms. Crystals 2020, 10, 589. [CrossRef]

18. Silva Viana, R.L.; Pereira Fidelis, G.; Jane Campos Medeiros, M.; Antonio Morgano, M.; Gabriela Chagas Faustino Alves, M.; Domingues Passero, L.F.; Lima Pontes, D.; Cordeiro Theodoro, R.; Domingos Arantes, T.; Araujo Sabry, D.; et al. Green Synthesis of Antileishmanial and Antifungal Silver Nanoparticles Using Corn Cob Xylan as a Reducing and Stabilizing Agent. Biomolecules 2020, 10, 1235. [CrossRef] [PubMed]

19. Órdenes-Aenishanslins, N.; Anziani-Ostuni, G.; Monrás, J.P.; Tello, A.; Bravo, D.; Toro-Ascuy, D.; Soto-Rifo, R.; Prasad, P.N.; Pérez-Donoso, J.M. Bacterial Synthesis of Ternary CdSAg Quantum Dots through Cation Exchange: Tuning the Composition and Properties of Biological Nanoparticles for Bioimaging and Photovoltaic Applications. Microorganisms 2020, 8, 631. [CrossRef] 
20. Simões, M.F.; Ottoni, C.A.; Antunes, A. Mycogenic Metal Nanoparticles for the Treatment of Mycobacterioses. Antibiotics 2020, 9, 569. [CrossRef]

21. Tomah, A.A.; Alamer, I.S.A.; Li, B.; Zhang, J.-Z. Mycosynthesis of Silver Nanoparticles Using Screened Trichoderma Isolates and Their Antifungal Activity against Sclerotinia sclerotiorum. Nanomaterials 2020, 10, 1955. [CrossRef] [PubMed]

22. Ahmad, A.; Senapati, S.; Khan, M.I.; Kumar, R.; Sastry, M. Extra-/intracellular, biosynthesis of gold nanoparticles by an alkalotolerant fungus, Trichothecium sp. J. Biomed. Nanotechnol. 2005, 1, 47-53. [CrossRef]

23. Kowshik, M.; Arhtaputre, S.; Kharrazi, S.; Vogel, W.; Urban, J.; Kulkarni, S.K.; Paknikar, K.M. Extracellular synthesis of silver nanoparticles by a silver-tolerant yeast strain MKY3. Nanotechnology 2003, 14, 95-100. [CrossRef]

24. Scala, A.; Piperno, A.; Hada, A.; Astilean, S.; Vulpoi, A.; Ginestra, G.; Marino, A.; Nostro, A.; Zammuto, V.; Gugliandolo, C. Marine Bacterial Exopolymers-Mediated Green Synthesis of Noble Metal Nanoparticles with Antimicrobial Properties. Polymers 2019, 11, 1157. [CrossRef] [PubMed]

25. Huq, M.A. Green Synthesis of Silver Nanoparticles Using Pseudoduganella eburnea MAHUQ-39 and Their Antimicrobial Mechanisms Investigation against Drug Resistant Human Pathogens. Int. J. Mol. Sci. 2020, 21, 1510. [CrossRef] [PubMed]

26. Merzlyak, A.; Lee, S.W. Phage as template for hybrid materials and mediators for nanomaterials synthesis. Curr. Opin. Chem. Biol. 2006, 10, 246-252. [CrossRef] [PubMed]

27. Li, X.; Xu, H.; Chen, Z.; Chen, G. Biosynthesis of nanoparticles by microorganisms and their applications. J. Nanomater. 2011, 2011, 16. [CrossRef]

28. Narayanan, K.B.; Sakthivel, N. Biological synthesis of metal nanoparticles by microbes. Adv. Colloid Interface Sci. 2010, 156, 1-13. [CrossRef]

29. Phan, T.T.V.; Huynh, T.-C.; Manivasagan, P.; Mondal, S.; Oh, J. An Up-To-Date Review on Biomedical Applications of Palladium Nanoparticles. Nanomaterials 2020, 10, 66. [CrossRef]

30. Dreyfuss, M.S.; Chipley, J.R. Comparison of effects of sublethal microwave radiation and conventional heating on the metabolic activity of Staphylococcus aureus. Appl. Environ. Microbiol. 1980, 39, 13-16. [CrossRef]

31. Khanna, P.; Kaur, A.; Goyal, D. Algae-based metallic nanoparticles: Synthesis, characterization and applications. J. Microbiol. Methods 2019, 163, 105656. [CrossRef] [PubMed]

32. Venkatesan, J.; Lowe, B.; Anil, S.; Manivasagan, P.; Kheraif, A.A.A.; Kang, K.H.; Kim, S.K. Seaweed polysaccharides and their potential biomedical applications. Starch Stärke 2015, 67, 381-390. [CrossRef]

33. Mukunthan, K.; Balaji, S. Cashew apple juice (Anacardium occidentale L.) speeds up the synthesis of silver nanoparticles. Int. J. Green Nanotechnol. 2012, 4, 71-79. [CrossRef]

34. Kharissova, O.V.; Dias, H.V.R.; Kharisov, B.I.; Perez, B.O.; Victor, M.; Perez, J. The greener synthesis of nanoparticles. Trends Biotechnol. 2013, 31, 240. [CrossRef] [PubMed]

35. Bhattacharya, D.; Gupta, R.K. Nanotechnology and potential of microorganisms. Crit. Rev. Biotechnol. 2005, 25, 199-204. [CrossRef] [PubMed]

36. Mandal, D.; Bolander, M.E.; Mukhopadhyaya, D.; Sarkar, G.; Mukherjee, P. The use of microorganism for the formation of metal nanoparticles and their applications. Appl. Microbiol. Biotechnol. 2006, 69, 485-492. [CrossRef] [PubMed]

37. Ahmad, N.; Sharma, S.; Alam, M.K.; Singh, V.N.; Shamsi, S.F.; Mehta, B.R.; Fatma, A. Rapid synthesis of silver nanoparticles using dried medicinal plant of basil. Colloids Surf. B 2010, 81, 81-86. [CrossRef]

38. Shankar, S.S.; Rai, A.; Ankamwar, B.; Singh, A.; Ahmad, A.; Sastry, M. Biological synthesis of triangular gold nanoprisms. Nat. Mater. 2004, 3, 482-488. [CrossRef]

39. Kasthuri, J.; Kathiravan, K.; Rajendiran, N. Phyllanthin-assisted biosynthesis of silver and gold nanoparticles: A noval biological approach. J. Nanopart. Res. 2009, 11, 1075-1085. [CrossRef]

40. Azzazy, H.M.E.; Mansour, M.M.H.; Samir, T.M.; Franco, R. Gold nanoparticles in the clinical laboratory: Principles of preparation and applications. Clin. Chem. Lab Med. 2012, 50, 193-209. [CrossRef]

41. Marslin, G.; Siram, K.; Maqbool, Q.; Selvakesavan, R.K.; Kruszka, D.; Kachlicki, P.; Franklin, G. Secondary Metabolites in the Green Synthesis of Metallic Nanoparticles. Materials 2018, 11, 940. [CrossRef] [PubMed] 
42. Sankar, R.; Manikandan, P.; Malarvizhi, V.; Fathima, T.; Shivashangari, K.S.; Ravikumar, V. Green synthesis of colloidal copper oxide nanoparticles using Carica papaya and its application in photocatalytic dye degradation. Spectrochim. Acta Part A 2014, 121, 746. [CrossRef] [PubMed]

43. Castro, L.; Blázquez, M.L.; Muñoz, J.A.; González, F.; García-Balboa, C.; Ballester, A. Biosynthesis of gold nanowires using sugar beet pulp. Process Biochem. 2011, 46, 1076. [CrossRef]

44. Wang, M.; Li, H.; Li, Y.; Mo, F.; Li, Z.; Chai, R.; Wang, H. Dispersibility and Size Control of Silver Nanoparticles with Anti-Algal Potential Based on Coupling Effects of Polyvinylpyrrolidone and Sodium Tripolyphosphate. Nanomaterials 2020, 10, 1042. [CrossRef] [PubMed]

45. Sathishkumar, M.; Krishnamurthy, S.; Yun, Y.S. Immobilization of silver nanoparticles synthesized using the Curcuma longa tuber powder extract on cotton cloth for bactericidal activity. Biores. Technol. 2010, 101, 7958-7965. [CrossRef] [PubMed]

46. Ghoreishi, S.M.; Behpour, M.; Khayatakashani, M. Green synthesis of silver and gold nanoparticles using Rosa damascena and its primary applications in electrochemistry. Phys. E 2011, 44, 97-104. [CrossRef]

47. Duran, N.; Marcato, P.D.; Duran, M.; Yadav, A.; Gade, A.; Rai, M. Mechanistic aspects in the biogenic synthesis of extracellular metal nanoparticles by peptides, bacteria, fungi, and plants. Appl. Microbiol. Biotechnol. 2011, 90, 1609-1624. [CrossRef] [PubMed]

48. Punjabi, K.; Choudhary, P.; Samant, L.; Mukhejee, S.; Vaidya, S.; Chowdhary, A. Biosynthesis of Nanoparticles: A Review. Int. J. Pharm. Sci. Rev. Res. 2015, 30, 219.

49. Malik, P.; Shankar, R.; Malik, V.; Sharma, N.; Mukherjee, T.K. Green chemistry based benign routes for nanoparticle synthesis. J. Nanopart. 2014, 2014, 302429. [CrossRef]

50. Fahmy, S.A.; Preis, E.; Bakowsky, U.; Azzazy, H.M.E.-S. Palladium Nanoparticles Fabricated by Green Chemistry: Promising Chemotherapeutic, Antioxidant and Antimicrobial Agents. Materials 2020, 13, 3661. [CrossRef]

51. Feldheim, D.L.; Foss, C.A. Metal Nanoparticles: Synthesis, Characterization, and Applications; CRC Press: Boca Raton, FL, USA, 2002.

52. Shahverdi, A.R.; Shakibaie, M.; Nazari, P. Basic and practical procedures for microbial synthesis of nanoparticles. In Metal Nanoparticles in Microbiology; Rai, M., Duran, N., Eds.; Springer: Berlin, Germany, 2011; pp. 177-197.

53. Yamada, M.; Foote, M.; Prow, T.W. Therapeutic gold, silver, and platinum nanoparticles. Wiley Interdiscip. Rev. Nanomed. Nanobiotechnol. 2015, 7, 428-445. [CrossRef] [PubMed]

54. Zou, C.; Yang, B.; Bin, D.; Wang, J.; Li, S.; Yang, P.; Wang, C.; Shiraishi, Y.; Du, Y. Electrochemical synthesis of gold nanoparticles decorated flower-like graphene for high sensitivity detection of nitrite. J. Colloid Interface Sci. 2017, 488, 135-141. [CrossRef] [PubMed]

55. Liu, F.; Liu, J.; Cao, X. Microwave-assisted synthesis silver nanoparticles and their surface enhancement raman scattering. Rare Met. Mater. Eng. 2017, 46, 2395-2398.

56. Nadimpalli, N.K.V.; Bandyopadhyaya, R.; Runkana, V. Thermodynamic analysis of hydrothermal synthesis of nanoparticles. Fluid Phase Equilib. 2018, 456, 33-45. [CrossRef]

57. Kumar, A.; Joshi, H.M.; Mandale, A.B.; Srivastava, R.; Adyanthaya, S.D.; Pasricha, R.; Sastry, M. Phase transfer of platinum nanoparticles from aqueous to organic solutions using fatty amine molecules. J. Chem. Sci. 2004, 116, 293-300. [CrossRef]

58. Khan, Z.U.H.; Khan, A.; Chen, Y.; Shah, N.S.; Muhammad, N.; Khan, A.U.; Tahir, K.; Khan, F.U.; Murtaza, B.; Hassan, S.U.; et al. Biomedical applications of green synthesized Nobel metal nanoparticles. J. Photochem. Photobiol. B Biol. 2017, 173, 150-164. [CrossRef]

59. Nath, D.; Banerjee, P. Green nanotechnology_A new hope for medical biology. Environ. Toxicol. Pharmacol. 2013, 36, 997-1014. [CrossRef]

60. Mashwani, Z.-R.; Khan, M.A.; Khan, T.; Nadhman, A. Applications of plant terpenoids in the synthesis of colloidal silver nanoparticles. Adv. Colloid Interface Sci. 2016, 234, 132-141. [CrossRef]

61. Thirumurugan, A.; Aswitha, P.; Kiruthika, C.; Nagarajan, S.; Christy, A.N. Green synthesis of platinum nanoparticles using Azadirachta indica-An eco-friendly approach. Mater. Lett. 2016, 170, 175-178. [CrossRef]

62. Ayguna, A.; Gülbagcaa, F.; Ozerb, L.Y.; Ustaogluc, B.; Altunogluc, Y.C.; Balogluc, M.C.; Atalard, M.N.; Almae, M.H.; Sena, F. Biogenic platinum nanoparticles using black cumin seed and their potential usage as antimicrobial and anticancer agent. J. Pharm. Biomed. Anal. 2020, 179, 112961. [CrossRef] 
63. Kumar, K.M.; Mandal, B.K.; Tammina, S.K. Green synthesis of nano platinum using naturally occurring polyphenols. RSC Adv. 2013, 3, 4033. [CrossRef]

64. Alshatwi, A.A.; Periasamy, J.A.; Subbarayan, V. Green synthesis of platinum nanoparticles that induce cell death and G2/M-phase cell cycle arrest in human cervical cancer cells. J. Mater. Sci. Mater. Med. 2015, $26,7$. [CrossRef] [PubMed]

65. Soundarrajan, C.; Sankari, A.; Dhandapani, P.; Maruthamuthu, S.; Ravichandran, S.; Sozhan, G.; Palaniswamy, N. Rapid biological synthesis of platinum nanoparticles using Ocimum sanctum for water electrolysis applications. Bioprocess Biosyst. Eng. 2012, 35, 827-833. [CrossRef] [PubMed]

66. Prabhu, N.; Gajendran, T. Green Synthesis of Noble Metal of Platinum Nanoparticles from Ocimum sanctum (Tulsi) Plant- Extracts. J. Biotechnol. Biochem. 2017, 3, 107-112. [CrossRef]

67. Sahin, B.; Aygün, A.; Gündüz, H.; Sahin, K.; Demir, E.; Akocak, S.; Sen, F. Cytotoxic effects of platinum nanoparticles obtained from pomegranate extract by the green synthesis method on the MCF-7 cell line. Colloids Surf. B Biointerfaces 2018, 163, 119-124. [CrossRef] [PubMed]

68. Song, J.Y.; Kwon, E.Y.; Kim, B.S. Biological synthesis of platinum nanoparticles using Diopyros kaki leaf extract. Bioprocess Biosyst. Eng. 2010, 33, 159-164. [CrossRef]

69. Sheny, D.S.; Philip, D.; Mathew, J. Synthesis of platinum nanoparticles using dried Anacardium occidentale leaf and its catalytic and thermal applications. Spectrochim. Acta A Mol. Biomol. Spectrosc. 2013, 114, 267-271. [CrossRef] [PubMed]

70. Nellore, J.; Pauline, C.; Amarnath, K. Bacopa monnieri Phytochemicals Mediated Synthesis of Platinum Nanoparticles and Its Neurorescue Effect on 1-Methyl 4-Phenyl 1,2,3,6 Tetrahydropyridine-Induced Experimental Parkinsonism in Zebrafish. J. Neurodegener. Dis. 2013, 2013, 1-8. [CrossRef] [PubMed]

71. Vinod, V.; Saravanan, P.; Sreedhar, B.; Devi, D.K.; Sashidhar, R. A facile synthesis and characterization of $\mathrm{Ag}, \mathrm{Au}$ and Pt nanoparticles using a natural hydrocolloid gum kondagogu (Cochlospermum gossypium). Colloids Surf. B Biointerfaces 2011, 83, 291-298. [CrossRef]

72. Ghosh, S.; Nitnavare, R.; Dewle, A.; Tomar, G.B.; Chippalkatti, R.; More, P.; Chopade, B.A. Novel platinum-palladium bimetallic nanoparticles synthesized by Dioscorea bulbifera: Anticancer and antioxidant activitiesInt. J. Nanomed. 2015, 10, 7477-7490.

73. Depciuch, J.; Stec, M.; Maximenko, A.; Drzymała, E.; Pawlyta, M.; Baran, J.; Parlinska-Wojtan, M. Synthesis method-dependent photothermal effects of colloidal solutions of platinum nanoparticles used in photothermal anticancer therapy. Appl. Organometal. Chem. 2020, 34, e5401. [CrossRef]

74. Dobrucka, R.; Romaniuk-Drapała, A.; Kaczmarek, M. Evaluation of biological synthesized platinum nanoparticles using Ononidis radix extract on the cell lung carcinoma A549. Biomed. Microdevices 2019, 21, 75. [CrossRef]

75. Ullah, S.; Ahmad, A.; Wang, A.; Raza, M.; Jan, A.U.; Tahir, K.; Rahman, A.U.; Qipeng, Y. Bio-fabrication of catalytic platinum nanoparticles and their in vitro efficacy against lungs cancer cells line (A549). J. Photochem. Photobiol. B Biol. 2017, 173, 368-375. [CrossRef] [PubMed]

76. Yang, C.; Wang, M.; Zhou, J.; Chi, Q. Bio-synthesis of peppermint leaf extract polyphenols capped nano-platinum and their in-vitro cytotoxicity towards colon cancer cell lines (HCT 116). Mater. Sci. Eng. C 2017, 77, 1012-1016. [CrossRef] [PubMed]

77. Tahir, K.; Nazir, S.; Ahmad, A.; Li, B.; Khan, A.U.; Khan, Z.U.H.; Khan, F.U.; Khan, Q.U.; Khan, A.; Rahman, A.U. Facile and green synthesis of phytochemicals capped platinum nanoparticles and in vitro their superior antibacterial activity. J. Photochem. Photobiol. B Biol. 2017, 166, 246-251. [CrossRef] [PubMed]

78. Velmurugan, P.; Shim, J.; Kim, K.; Oh, B.T. Prunus $\times$ yedoensis tree gum mediated synthesis of platinum nanoparticles with antifungal activity against phytopathogens. Mater. Lett. 2016, 174, 61-65. [CrossRef]

79. Anyik, J.L.; Oluwafemi, O.S. Plant-mediated synthesis of platinum nanoparticles using water hyacinth as an efficient biomatrix source-An eco-friendly development. Mater. Lett. 2017, 196, 141-144.

80. Nadaroglu, H.; Gungor, A.A.; Ince, S.; Babagil, A. Green synthesis and characterisation of platinum nanoparticles using quail egg yolk. Spectrochim. Acta Part A Mol. Biomol. Spectrosc. 2017, 172, 43-47. [CrossRef] [PubMed]

81. Baskaran, B.; Muthukumarasamy, A.; Chidambaram, S.; Sugumaran, A.; Ramachandran, K.; Rasu Manimuthu, T. Cytotoxic potentials of biologically fabricated platinum nanoparticles from Streptomyces sp. on MCF-7 breast cancer cells. IET Nanobiotechnol. 2017, 11, 241-246. [CrossRef] [PubMed] 
82. Gaidhani, S.V.; Yeshvekar, R.K.; Shedbalkar, U.U.; Bellare, J.H.; Chopade, B.A. Bio-reduction of hexachloroplatinic acid to platinum nanoparticles employing Acinetobacter calcoaceticus. Process. Biochem. 2014, 49, 2313-2319. [CrossRef]

83. Gholami-Shabani, M.; Gholami-Shabani, Z.; Shams-Ghahfarokhi, M.; Akbarzadeh, A.; Riazi, G.; Razzaghi-Abyaneh, M. Biogenic Approach using Sheep Milk for the Synthesis of Platinum Nanoparticles: The Role of Milk Protein in Platinum Reduction and Stabilization. Int. J. Nanosci. Nanotechnol. 2016, 12, $199-206$.

84. Venu, R.; Ramulu, T.S.; Anandakumar, S.; Rani, V.S.; Kim, C.G. Bio-directed synthesis of platinum nanoparticles using aqueous honey solutions and their catalytic applications. Colloid Surf. A 2011, 384, 733-738. [CrossRef]

85. Chen, L.; Wang, N.; Wang, X.; Ai, S. Protein-directed in situ synthesis of platinum nanoparticles with superior peroxidase-like activity, and their use for photometric determination of hydrogen peroxide. Microchim. Acta 2013, 180, 1517-1522. [CrossRef]

86. Ramkumar, V.S.; Pugazhendhi, A.; Prakash, S.; Ahila, N.K.; Vinoj, G.; Selvam, S.; Kumar, G.; Kannapiran, E.; Rajendran, R.B. Synthesis of platinum nanoparticles using seaweed Padina gymnospora and their catalytic activity as PVP/PtNPs nanocomposite towards biological applications. Biomed. Pharmacother. 2017, 92, 479-490. [CrossRef] [PubMed]

87. Shiny, P.J.; Mukherjee, A.; Chandrasekaran, N. DNA damage and mitochondria-mediated apoptosis of A549 lung carcinoma cells induced by biosynthesised silver and platinum nanoparticles. RSC Adv. 2016, 6, 27775.

88. Syed, A.; Ahmad, A. Extracellular biosynthesis of platinum nanoparticles using the fungus Fusarium oxysporum. Colloids Surf. B Biointerfaces 2012, 97, 27-31. [CrossRef] [PubMed]

89. Manikandan, M.; Hasan, N.; Wu, H.-F. Platinum nanoparticles for the photothermal treatment of Neuro 2A cancer cells. Biomaterials 2013, 34, 5833-5842. [CrossRef] [PubMed]

90. Konieczny, P.; Goralczyk, A.G.; Szmyd, R.; Skalniak, L.; Koziel, J.; Filon, F.L.; Crosera, M.; Cierniak, A.; Zuba-Surma, E.K.; Borowczyk, J.; et al. Effects triggered by platinum nanoparticles on primary keratinocytes. Int. J. Nanomed. 2013, 8, 3963-3975.

Publisher's Note: MDPI stays neutral with regard to jurisdictional claims in published maps and institutional affiliations.

(C) 2020 by the authors. Licensee MDPI, Basel, Switzerland. This article is an open access article distributed under the terms and conditions of the Creative Commons Attribution (CC BY) license (http://creativecommons.org/licenses/by/4.0/). 